\title{
Study Of Serum Lipid Profile In Pre-Eclampsia And Eclampsia
}

\author{
NAF Islam ${ }^{1}$, MAR Chowdhury ${ }^{2}$, GM Kibria $^{3}$, S Akhter $^{4}$
}

\begin{abstract}
The present study was designed to evaluate the association of lipid profile in pre- eclampsia and eclampsia. This case-control study was carried out in the department of biochemistry, M.A.G. Osmani Medical College, Sylhet, during July 2005 to June 2006. Total 100 study subjects were evaluated, 40 normotensive pregnant women (mean age $24.90 \pm 4.04$ ) as normal and 60 already diagnosed preeclamptic \& eclamptic women (mean age 24.17 \pm 4.90 ) as study group. Age range was 15-45 years, gestational age 24 weeks to term were included. Patients with pre-existing hypertension were excluded. Serum lipid profile (total lipids, cholesterol, triglycerides, HDL-cholesterol and LDLcholesterol) of hundred women with Pre-eclampsia and Eclampsia $(n=60)$, normotensive women $(n=40)$ were monitored. The preeclampsia was associated with a significant rise in triglyceride (225.6 \pm 28.93 vs $165.6 \pm 17.22)$ and fall in HDL cholesterol concentration ( $42.4 \pm 9.29$ vs $55.7 \pm 7.11)$, while eclamptic women showed significant fall in HDL cholesterol (41.8 \pm 8.79 vs $55.7 \pm 7.11)$ and rise in LDL cholesterol (133.4 \pm 11.75 vs $115.2 \pm 10.72)$ as compared to normal pregnant women. Lipid metabolism plays a key role in the pathophysiology of Pre-eclampsia and Eclampsia. Increased triglycerides levels along with decreased HDL-cholesterol levels and delayed triglycerides clearance and high blood pressure are associated with development of preeclampsia and eclampsia. This association may be significant in understanding the pathologic processes of preeclampsia and may help in developing strategies for prevention or early diagnosis of the disorder.
\end{abstract}

Key Words: Preeclampsia, High Density Lipoproteins, Triglycerides, Low Density Lipoprotein.

\section{Introduction}

Pre-eclampsia (PE), a non-convulsive form of pregnancy-induced hypertension, accounts for a significant proportion of maternal and fetal morbidity and mortality ${ }^{1}$. Pre-eclampsia when complicated with convulsion is called eclampsia. The disorder complicates approximately 5 to 7 percent of pregnancies $^{2-4}$. In a survey for assessment of emergency obstetric care (EOC) in Bangladesh, $5 \%$ of total obstetrical admissions in health facility were due to pre-eclampsia and eclampsia. There are approximately 3.6 million births per year in Bangladesh. Over 100,000 women develop eclampsia per year. Eclampsia contributes $16 \%$ of maternal mortality

1. Dr. Nur-A-Farhana Islam, M Phil (Biochemistry), Associate Professor, Department of Biochemistry, NEMC, Sylhet.

2. Dr. Md. Anup Rahman Chowdhury, M Phil (Pharmacology), Assistant Professor, Department of Pharmacology, NEMC, Sylhet.

3. Dr. Golam Kibria, M Phil (Anatomy), Professor, Dept. of Anatomy, EMC, Savar, Dhaka.

4. Dr. Selina Akhter, MD (Transfusion Medicine), Assistant Professor, Dept. of Transfusion Medicine, ShSMC, Dhaka

Address of correspondence

Dr. Nur-A-Farhana Islam, M Phil (Biochemistry),

Associate Professor, Department of Biochemistry, NEMC, Sylhet.

Phone: +88-01726886411. E-mail: nurafarhanai@yahoo.com. on a national basis which is equivalent to about 4500 maternal death in one year. The risk of developing preeclampsia appears to be greater in women, who have family history of essential hypertension, and there may also be a relationship between risk of pre-eclampsia and the metabolic syndrome ${ }^{5}$. The most important feature in toxaemia of pregnancy is hypertension which is supposed to be due to vasospastic phenomenon in kidney, uterus, placenta and brain ${ }^{6}$. Altered lipid synthesis leading to decrease in PGI2: TXA2 ratio is also supposed to be an important way of pathogenesis in pregnancy induced hypertension ${ }^{7}$. Thus abnormal lipid metabolism seems important in the pathogenesis of pregnancy induced hypertension (PIH) too.

Pre-eclampsia and eclampsia is associated with substantial risks for the fetus. These include intrauterine growth restriction, death and prematurity with attendant complications where as the mother is at risk of renal failure, pulmonary edema, stroke, and death. Despite considerable research, the cause or causes of preeclampsia remain unclear and there are no clinically useful screening tests to identify women in whom it will develop ${ }^{8}$. Early pregnancy dyslipidemia is associated with an increased risk of Pre-eclampsia ${ }^{9}$. Women with a 
history of pre-eclampsia have significant differences in lipid parameters and an increased susceptibility to lipoprotein oxidation when compared with women who had normal pregnancy. Disorders of lipoprotein metabolism are reported to be a major cause of hypertension and proteinuria in Pre-eclampsia ${ }^{10}$. In view of the above findings it is postulated that alteration of lipid metabolism may play a key role in the development of symptoms of Pre-eclampsia and Eclampsia. The present study was designed to investigate the alteration in lipid profile (Cholesterol, triglycerides, HDL-cholesterol, LDL-cholesterol and total lipids) in normal, pre-eclamptic and eclamptic women.

\section{Materials and Methods}

It was a case control study, done in the department of Biochemistry, Sylhet M.A.G Osmani Medical College, from July 2005 to June 2006. Total 100 pregnant women of 15-45 years, were selected and grouped as follows. Group-I (Controls): 40 Normotensive pregnant women; Group-II (Cases): 60 pre-eclamptic or eclamptic subjects. Group-II was subdivided into a) Group IIa- Pre-eclampsia (30) \& Group IIb- Eclampsia (30). Inclusion criteria were primi, gestational age 24 weeks to term. Exclusion criteria- pre-existing hypertension, IHD, CRF, DM, treatment with drugsmay influence lipid profile. The preeclamptic patients were diagnosed by the presence of persistent hypertension (more than 140/90 $\mathrm{mm}$ of $\mathrm{Hg}$ ), gross proteinuria (tested by heat test of urine), and pathological oedema. The eclamptic patients were diagnosed by the additional feature of convulsion or coma. All the subjects of groups were in the third trimester. Blood samples were drawn from all the subjects following a fast of 12 hours and analyzed for Serum Triglycerides (TG), Total cholesterol (TC) and HDL cholesterol (HDL-C) by enzymatic methods with the help of Glaxo kits on ERBA Chem-5 semi auto analyzer in the department of biochemistry, Sylhet M.A.G Osmani Medical College. Data were statistically analyzed by Student's t test and significance was expressed in term of $p$ value.

\section{Results}

There was no significant difference of maternal and gestational age. Systolic, Diastolic, and Mean arterial pressure were $(110.75 \pm 8.88,159 \pm 18.47),(68 \pm$ $10.42,100.75 \pm 10.92),(82.25 \pm 9.46,120.16 \pm 12.04)$ $\mathrm{mm} \mathrm{Hg}$ in Group I (Controls) \& Group II (cases) respectively (Table I). There was significant difference of all blood pressure parameter between cases \& controls $(\mathrm{p}<0.001)$. Serum lipid profile was compared between cases \& controls \& between subgroups of cases. Mean Triglycerides $(225.6 \pm 28.93$ vs $165.6 \pm$ 17.22) levels are significantly higher in group of women who had preeclampsia as compare to normal controls $(\mathrm{p}<0.05)$ as shown in Table-II. While mean High density lipoproteins cholesterol $(42.4 \pm 9.29$ vs $55.7 \pm 7.11)$ levels were significantly lower in women with preeclampsia than in normal control subjects $(\mathrm{p}<0.05)$ as shown in Table-II. In Case of eclampsia mean LDL cholesterol (133.4 \pm 11.75 vs $115.2 \pm 10.72)$ are significantly higher and mean High density lipoproteins' cholesterol $(41.8 \pm 8.79$ vs $55.7 \pm 7.11)$ levels were significantly lower than in normal control subjects $(p<0.05)$ (Table- II). Mean cholesterol levels were not statistically different between pre-eclamptic, eclamptic and normal subjects as shown in Table-II.

Results are summarized in tabulated form.

Table I: Demographic and Clinical Characteristics of Controls and Study subjects

\begin{tabular}{lll}
\hline Parameter & Group I Controls $(\mathrm{n}=40)$ & Group II Cases $(\mathrm{n}=30)$ \\
\hline $\begin{array}{l}\text { Maternal age (year) } \\
\text { mean } \pm \text { SD }\end{array}$ & $24.90 \pm 4.04$ & $24.17 \pm 4.90$ \\
$\begin{array}{l}\text { Gestational age (week) } \\
\text { mean } \pm \text { SD }\end{array}$ & $32.75 \pm 5.18$ & $34.48 \pm 3.05$ \\
$\begin{array}{l}\text { Systolic BP (mm Hg) } \\
\text { mean } \pm \text { SD }\end{array}$ & $110.75 \pm 8.88$ & $159 \pm 18.47^{*}$ \\
$\begin{array}{l}\text { Diastolic BP (mm Hg) } \\
\text { mean } \pm \text { SD }\end{array}$ & $68 \pm 10.42$ & $100.75 \pm 10.92^{*}$ \\
$\begin{array}{l}\text { MAP (mm Hg) } \\
\text { mean } \pm \text { SD }\end{array}$ & $82.25 \pm 9.46$ & $120.16 \pm 12.04^{*}$ \\
\hline
\end{tabular}

$* \mathrm{p}<0.05$ as compared to normal control.

Table II: Lipid profile in normal pregnancy (Group I), Pre-eclampsia (Group IIa) and Eclampsia (Group IIb)

\begin{tabular}{|c|c|c|c|c|}
\hline Parameters & $\begin{array}{c}\text { Group I } \\
\text { Controls } \\
(\mathrm{n}=40) \\
\text { mean } \pm \text { SD }\end{array}$ & $\begin{array}{c}\text { Group IIa } \\
\text { Pre-eclampsia } \\
\quad(\mathrm{n}=30) \\
\text { mean } \pm \text { SD }\end{array}$ & $\begin{array}{c}\text { Group IIb } \\
\text { Eclampsia } \\
(\mathrm{n}=30) \\
\text { mean } \pm \mathrm{SD}\end{array}$ & $\begin{array}{c}\text { Statistical relation } \\
\text { with Group I }\end{array}$ \\
\hline $\begin{array}{l}\text { Triglyceride } \\
(\mathrm{mg} / \mathrm{dl})\end{array}$ & $165.6 \pm 17.22$ & $225.6 \pm 28.93$ & $203.2 \pm 49.20$ & $\begin{array}{l}\mathrm{P}<0.05 \text { in Group } \\
\text { IIa, } \mathrm{P}>0.05 \text { in } \\
\text { Group IIb }\end{array}$ \\
\hline $\begin{array}{l}\text { Total cholesterol } \\
(\mathrm{mg} / \mathrm{dl})\end{array}$ & $169.0 \pm 17.03$ & $186.3 \pm 34.43$ & $180.5 \pm 26.92$ & $\begin{array}{l}\mathrm{P}>0.05 \text { in Group } \\
\text { IIa, } \mathrm{P}>0.05 \text { in } \\
\text { Group IIb }\end{array}$ \\
\hline $\begin{array}{l}\text { HDL-Cholesterol } \\
(\mathrm{mg} / \mathrm{dl})\end{array}$ & $55.7 \pm 7.11$ & $42.4 \pm 9.29$ & $41.8 \pm 8.79$ & $\begin{array}{l}\mathrm{P}<0.01 \text { in Group } \\
\text { IIa, } \mathrm{P}<0.05 \text { in } \\
\text { Group IIb }\end{array}$ \\
\hline $\begin{array}{l}\text { LDL-Cholesterol } \\
(\mathrm{mg} / \mathrm{dl})\end{array}$ & $115.2 \pm 10.72$ & $134.4 \pm 24.26$ & $133.4 \pm 11.75$ & $\begin{array}{l}\mathrm{P}>0.05 \text { in Group } \\
\text { IIa, } \mathrm{P}<0.05 \text { in } \\
\text { Group IIb }\end{array}$ \\
\hline
\end{tabular}




\section{Discussion}

In this study we investigate the role of lipid profile in the occurrence of Pre-eclampsia and Eclampsia. There was a positive correlation between Preeclampsia and lipid parameters as shown in Table-II. Serum triglyceride concentration rise more significantly in pre-eclampsia in our study which corroborated with the findings of many workers ${ }^{11,12}$. The principle modulator of this hypertriglyceridemia is oestrogen as pregnancy is associated with hyperoestrogenaemia. Oestrogen induces hepatic biosynthesis of endogenous triglycerides, which is carried by VLDL ${ }^{13}$. This process may be modulated by hyperinsulinism found in pregnancy ${ }^{14}$. Increased TG, found in pregnancy induced hypertension, is likely to be deposited in predisposed vessels, such as the uterine spiral arteries and contributes to the endothelial dysfunction, both directly and indirectly through generation of small, dense $\mathrm{LDL}^{15}$. Moreover, this hypertriglyceridemia may be associated with hypercoagulability ${ }^{16}$. In our study, in contrast to normal pregnant women, the rise in serum TG was statistically significant $(\mathrm{p}<0.05)$ in preeclamptic patients, but not so significant in eclamptic patients $(p>0.05)$. This finding can be explained as because the eclamptic process is very frequently associated with aggravated hepatic damage which inhibits the enhanced de novo synthesis of triglyceride in liver. Moreover, VLDL which carries the endogenous triglyceride is also synthesized in the liver and the increase in triglyceride in gestation is estimated mainly in the VLDL ${ }^{17}$.

In present study no significant alteration in Total Cholesterol level could be observed in third trimester of normal pregnancy in any of the groups. These findings are similar to Sattar et al ${ }^{15}$. However others have found significant increase in serum $\mathrm{TC}$ in toxaemia of pregnancy ${ }^{14,18}$.

In our study a significant decrease in HDL-C were observed in pre-eclamptic and eclamptic pregnant women. Oestrogen is responsible for induction of TG and HDL and suppression of serum LDL and oestrogen level falls in preeclampsia ${ }^{6,19}$. The Low level of HDL in pre-eclampsia is however not only because of hypooestrogenaemia but also due to insulin resistance ${ }^{20}$.

A significant fall in LDL-C level in third trimester of normal pregnancy as observed in present study may be attributed to hyperestrogenaemia, while LDL-C level increases significantly in eclampsia \& pre-eclampsia.
A significantly higher level of beta-lipoprotein was also reported by many workers in third trimester of gestational proteinuric hypertension ${ }^{18,21,22}$.

In summary, the findings reported in this study suggest that the women who develop pre-eclampsia and eclampsia had disturbed lipid profile due to abnormal lipid metabolism. Increased triglycerides levels and delayed triglycerides clearance and high blood pressure are the reasons for the development of preeclampsia \& eclampsia. This association may be significant in understanding the pathological process of preeclampsia and may help in developing strategies for prevention and early diagnosis of pre-eclampsia and eclampsia.

\section{References}

1. Vanderjagt DJ, Patel RJ, El-Nafaty AU, Melah GS, Crossey MJ, Glew RH. High density lipoprotein and homocysteine levels correlate inversely in preeclamptic women in northern Nigeria. Acta Obstet Gyneacol Scand. 2004;83(6):536-42.

2. Jimenez DM, Pocovi M, Ramon-Cajal J, Romero MA, Martinez H, Grande F. Longitudinal study of plasma lipids and lipoprotein cholesterol in normal pregnancy and puerperium. Gynecol Obstet Invest. 1988;25(3):158-64.

3. Dutta DC. Hypertensive disorders in pregnancy. 6th edition. Hiralal K. editor. In: Text Book of Obstetrics. New Central Book Agency Kolkata, India; 2005. p. 222-223.

4. Nahar S, Begum S, Yasnur S, Rasul CH. Use of misoprostotol for induction of labour in unfavorable cervix in eclampsia. Pak J Med Sci. 2004;20 (3):181-185.

5. Packer CS. Biochemical markers and physiological parameters as indices for identifying patients at risk of developing preeclampsia. J Hypertens. 2005;23:(1)45-6.

6. Dutta DC. Hypertensive disorders in pregnancy, 5th edition. Konar HL.editor. In: Textbook of Obstetrics. New Central Book Agency, Kolkata, India; 2001. p. 234-55.

7. Robson, SC. Hypertension and renal disease in pregnancy. 6th edition. Edmonds DK. editor. In: Dewhurst's Textbook of Obstetrics and Gynaecology for postgraduates. Blackwell Science, New York; 1999. p 167-9

8. Caren G, Solomon, Seely EW. Preeclampsia searching for cause. New Eng J Med. 2004;350(7):641-2.

9. Enquobahrie DA, Williams MA, Butler CL, Frderick IO, Miller RS, Luthy DA. Maternal plasma lipid concentration in early pregnancy and risk of preeclampsia. Am J Hypertens. 2004;17(7):574-81.

10. Gractacose E, Casals E, Gomez O, Llurba E, Mercader I, Carach $\mathrm{V}$, et al. Increased susceptibility to low density lipoprotein oxidation in women with a history of pr-eclampsia. Br J Obstet Gynaecol. 2003;110(4):400-4.

11. Enquobahrie, DA, Williams MA, Butler CL, Frederick IO, Miller RS and Luthy DA. Maternal plasma lipid concentrations in early pregnancy and risk of preeclampsia. Am J Hypertens.2004;17(7):574-81. 
12. Cekmen MB, Erbagci AB, Balat A, Duman C, Maral H, Ergen K, et al. Plasma lipid and lipoprotein concentrations in pregnancy induced hypertension. Clin. Biochem. 2003; 36(7):575-8.

13. Glueck CJ, Fallet RW, Scheel D. Effects of oestrogenic compounds on triglyceride kinetics. Metabolism. 1975;24:53745.

14. Adegoke OA, Iyare EE, Gbenebitse SO. Fasting plasma glucose and cholesterol levels in pregnant Nigerian women. Niger Postgrad Med J. 2003;10(1):32-6.

15. Sattar N, Bendomir A, Berry C, Shepherd J, Greer IA, Packard CJ. Lipoprotein sub fraction concentrations in preeclampsia: pathogenic parallels to atherosclerosis. Obstet Gynecol. 1997;89(3):403-8.

16. Kokia E, Barkai G, Reichman B, Segal P, Goldman B, Mashiach $\mathrm{S}$. Maternal serum lipid profile in pregnancies complicated by hypertensive disorders. J Perinat Med. 1990;18(6):473-8.

17. Yamaguchi K. Triglycerides and apoproteins in toxaemia of pregnancy. Nippon Sanka Fujika Gakkai Zasshi. 1988;40(2):1875-82.

18. Hubel CA, Lyall F, Weissfeld L, Gandley RE, Roberts JM. Small low-density lipoproteins and vascular cell adhesion molecule-1 are increased in association with hyperlipidemia in preeclampsia. Metabolism 1998;47(10):1281-8.

19. Bradley R, Crook D. Pregnancy, oral contraception and hormone replacement therapy. In: Textbook of Clinical Biochemistry: Metabolic and Clinical aspects. Marshall WJ, Bangert SK, editors.1st edition, Churchill Livingstone, London, 1995. p. 41322.

20. Kaaja R, Tirkkanen MJ, Viinnkka L, Ylikorkala O. Serum lipoproteins, insulin and urinary prostanoid metabolites in normal and hypertensive pregnant women. Obstet Gynecol. 1995;85(3):353-6.

21. Gratacos E, Casals E, Gomez O, Llurba E, Mercader I, Cararach V, Cabero L. Increased susceptibility to low density lipoprotein oxidation in women with a history of preeclampsia. $\mathrm{Br} \mathrm{J}$ of Obst \& Gynae.2003;110(4):400-4.

22. Wakatsuki A, Ikenoue N, Okatani Y, Shinohara K, Fukaya T. Lipoprotein particles in preeclampsia: susceptibility to oxidative modification. Obstet Gynecol. 2000;96(1):55-9. 